\title{
The development of foreign green credit business and its enlightenment to our country
}

\author{
Xiaolu Liu ${ }^{1, \mathrm{a}}$, Yuxuan Wang ${ }^{1, \mathrm{~b}}$, Xuan Pei ${ }^{1, \mathrm{c}}$, Xiao Liang ${ }^{1, \mathrm{~d}}$ \\ China Agricultural University \\ ${ }^{1}$ China Agricultural University, Beijing, China
}

\begin{abstract}
Green finance is one of the development trends of China's financial industry. Green credit and green bond are two main contents of green finance. This thesis aims to introduce the existing problems of green credit business in our country's commercial banks. Then try to put forward suggestions for the further improvement of green credit business in China relying on the introduction of the development of green credit business in the United States and Japan.
\end{abstract}

\section{Introduction}

After the reform and opening up, Chinese economy developed vigorously. However, while the extensive economic development model has made our country's economic volume continue to increase, the damage to the natural ecological environment has also become more serious.On July 12, 2007, the State Environmental Protection Administration, the People's Bank of China, and the China Banking Regulatory Commission jointly issued relevant opinions on preventing credit risks in order to curb the blind expansion of high-polluting and high-energy-consuming enterprises. Green credit has gradually become a household name in the financial industry.

From a social perspective, the policy's proposal not only played the role of "financial leverage" to support the development of green and environmentally friendly enterprises, it also restrained the blind expansion of polluting enterprises, which is conducive to adjusting our country's economic development model, promoting the optimization and upgrading of industrial structure, and achieving economic Sustainable development, it also contributes to the construction of our country's ecological civilization. From the perspective of the individual society of banks, the proposal of this policy is conducive to providing banks with new profit growth points, injecting new vitality, and optimizing the bank's asset structure. At the same time, it is beneficial for commercial banks to promote their own sustainable development while responding to national policies and assuming social responsibilities.

Since the concept of green credit came into being, the relevant business of our country's commercial banks has been gradually developed in the course of exploration. Green credit business in developed countries was

aemail:s20203111974@cau.edu.cn, bemail:S20203111982@cau.edu.cn, cemail:B20203110733@cau.edu.cn,

demail:SY20203112099@cau.edu.cn proposed and implemented earlier than our country, and there are many experiences for us to learn from and absorb.

\section{Problems of green credit business of our country's commercial banks}

\subsection{The overall scale of green credit development of our country's commercial banks is relatively small, and the distribution among banks is uneven.}

Although the development of green credit business of various banks has been good in recent years, it is compared with the total loans of banks The balance, the proportion of green credit balance is still low, all floating within $9 \%$, and the smaller one is only maintained at about $1 \%$. The scale of green credit in our country is still small, and it is difficult to realize the original intention of solving environmental protection problems through financial leverage.Among the 16 listed banks in our country, Industrial and Commercial Bank of China, Bank of China, Agricultural Bank of China Construction Bank and Industrial Bank accounted for the top five green credit balances. As of the end of 2018, Industrial Bank's green credit balance accounted for $28.8 \%$ of total bank loans. , And continue to increase year by year.In comparison, other joint-stock banks are dwarfed. For example, Shanghai Pudong Development Bank accounted for $6.1 \%$, Huaxia Bank accounted for 3.5\%, China CITIC Bank accounted for $1.7 \%$, and China Merchants Bank accounted for $4.2 \% . \%$ the following. 
2.2 The types of green credit products of our country's commercial banks are still relatively single, and their innovation capabilities are insufficient.

Compared with the green credit products issued by commercial banks in developed countries, the types of green credit products of our country's commercial banks are still relatively single, and their innovation capabilities are also far different.And its business model is only limited to reducing the scale of loans to environmentally polluting companies and expanding the scale of credit to environmentally friendly companies. This single credit method is far behind the developed countries in the world.At present, the more popular innovative green products in the world mainly include project financing, auto loans, green credit cards, home equity loans, commercial construction loans, and housing mortgage loans. Although our country's Industrial Bank has been a pioneer in the green credit industry in the domestic banking industry, it has developed Multi-featured products such as green financial leasing, green buyer's credit, contract environmental service financing, contract energy management financing, etc. Judging from the actual domestic situation, it is quite difficult to promote these products further.

\section{Development of foreign green credit business}

\subsection{The development of green credit business in the United States}

Environmental risk is an issue that we have to pay attention to. The Love River pollution incident has become an incentive for the introduction of the "Super Fund Act" in the United States.It was the first site in American history to be repaired in accordance with the Superfund Act.If environmental risks are not controlled, financial risks will be triggered, and the prevention and control of environmental risks by financial means has become an important task for a country, and related businesses in the United States regarding green credit have also begun.

In the United States, almost all banks provide financial support for green industries and projects. The United States pays attention to the management of environmental risks and realized earlier that it needed to pass legislation to truly put green credit policies into practice.The US Congress passed the "Super Fund Act" in 1980, which innovatively emphasized the environmental responsibility of banks. The bill stipulates that before providing loans, banks have the responsibility to ensure that the borrower is responsible for the environment during the implementation of the project.

One of the first banks to sign the UN Environmental Declaration and implement the "Equator Principles" was Citibank in the United States. Citigroup has been at the forefront of green credit development.Its main target customers who have difficulty in providing loans are low- and middle-income customers. Its mortgage loan company cooperates with Sharp Electronics to purchase and install energy-saving and environmentally-friendly solar power systems for the public and other needs that help achieve energy-saving and environmental protection. Provide convenient financing channels; overall, the US green credit risk evaluation mechanism, green credit product innovation mechanism, and social supervision system for green credit development are relatively complete.Government-led incentive policies have also become an important guarantee for the sustainable development of green credit in the United States.

\subsection{The development of Japan's green credit business}

Green credit is a product that combines environmental protection and financial markets. The development of an industry should conform to the current general development trend of a country. Just as the environmental protection industry has attracted increasing attention today, the financial industry needs to contribute its strength to the overall development trend.

As a small country and a strong economic development country, Japan has always paid attention to environmental protection. At the same time when China just proposed the green credit policy, the organization and implementation of related policies in Japan have already begun to take shape, and related work has been carried out in an orderly manner.Japan has always been a pioneer in the development of green credit business, and its laws and regulations related to green credit business are rich and detailed, and have strong operability. The supervision and evaluation system of related policies in Japan is also quite complete. As we all know, good policies need a supervision and evaluation system to escort them in order to achieve optimal results.

The firm policy implementation attitude of the Japanese government provides a good market environment for the development of this business. At the same time, a series of specific measures such as the establishment of environmental protection subsidy funds, preferential loans for green environmental enterprises, and tax incentives for environmental. The work provides a scientific and sound execution channel.As the first bank in Japan to develop green credit business, Mizuho Bank is also the first "Equator Bank" in the Asia-Pacific region. After joining the "Equator Principles", it began to comprehensively consider the severe environmental and energy issues of many developing countries in the Asia-Pacific region.The development of the local economy has continuously developed a variety of innovative green credit products, While the scope of services continues to expand, the level of financing services has also been continuously improved. 


\section{The enlightenment of the development of foreign green credit business to our country}

\subsection{Local governments increase their participation in and emphasis on green credit business.}

Based on the development experience of the United States and Japan, one thing in common between the two is that the government attaches great importance to green credit business.Facing and solving problems positively, rather than avoiding them, is the attitude that governments and financial institutions should have when facing risks.our country's economy is developing vigorously, but the extensive economic development model has continuously increased the size of our country's economy, and at the same time it has caused more and more damage to the natural ecological environment.our country actively responds to environmental risks, and has elevated the response to environmental issues into a national strategy of great significance, which is quite forward-looking and has a sense of mission.At the same time, changing the development concept, increasing the participation and importance of local governments in the green credit business, and truly implementing the new credit policy is the first step to facilitate the smooth development of this business. It is the most powerful guarantee for implementation and, at the same time, our country actively assumes the responsibility of a great power, which is a concrete manifestation of benefiting the international community.

\subsection{Studying the complete system of green credit business development, unifying standards, and ensuring its scientific}

Scientific decision-making is the primary prerequisite. According to the laws of economic development, learn from relevant foreign experience and strategies, and combine such as the maturity of the national financial market, the national economic system and the specific development of relevant historical culture. At the same time, in the process of implementing relevant policies, the overall direction of the local government must always be consistent with that of the central government, and may be slightly adjusted in accordance with the actual development of the locality.A high degree of uniformity of policy measures and a high degree of consistency in implementation standards will greatly regulate the implementation process of policies.Developed countries abroad have formed a relatively complete and scientific risk measurement mechanism, product innovation mechanism and social supervision system for the development of green credit business.Relevant decision-making departments in our country should make scientific and prudent decisions, form a complete system related to it as soon as possible, and strive to form unified standards and requirements for information disclosure in various banks, and then gradually form a green credit business development model suitable for our country's specific reality.

\subsection{Improving relevant policies and regulations, and improving the manipuility of policies.}

The first rule of legislation has become the consensus of most people. In the process of implementing relevant policies and related laws and regulations, the government should focus on strengthening the cross-checking links between various departments. A complete supervision and evaluation system is a strong guarantee for policy implementation and a necessary condition for improving policy manipuility. Policy measures with strong manipuility will undoubtedly improve its implementation efficiency.The most prominent feature of the green credit business in the United States is that legislation takes the lead, and the relevant policies and regulations of Japan are also detailed and practical, which provides enlightenment for our country to further regulate and develop this business.In the initial stage of the implementation of this policy, economic benefits may not be obvious compared to environmental benefits, and banks, as for-profit companies, may have to be more conscious of responding to policies at the beginning. At this time, operational and mandatory policies and regulations appear extremely necessary.

\section{Author information}

Xiaolu Liu, female, born in June 1998 in Cangzhou, Hebei Province, majored in international trade, School of economics and management, China Agricultural University

Yuxuan Wang, female, born in July 1998 in Yantai, Shandong Province, majored in enterprise management, School of economics and management, China Agricultural University

Xuan Pei, male, born in March 1989 in Heishan, Liaoning Province, is a doctoral candidate in industrial economics from school of economics and management, China Agricultural University. Research directions: industrial economy, environmental economy, etc

Xiao Liang, female, born in October 1998 in Luoyang, Henan Province, majored in accounting, School of economics and management, China Agricultural University

\section{References}

1. Goss A, Roberts G S. The impact of corporate social responsibility on the cost of bank loans[J]. Journal of Banking \& Finance, 2011, 35(7): 1794-1810.

2. Climent F, Soriano P. Green and good? The investment performance of US environmental mutual funds[J]. Journal of Business Ethics, 2011, 103(2): 275-287.

3. Galema R, Plantinga A, Scholtens B. The stocks at 
stake: Return and risk in socially responsible investment[J]. Journal of Banking \& Finance, 2008, 32(12): 2646-2654.

4. Labatt S, White R R. Environmental finance: a guide to environmental risk assessment and financial products[M]. John Wiley \& Sons, 2003.

5. Kinoti $M$ W. Green marketing intervention strategies and sustainable development: A conceptual paper[J]. International journal of business and social science, 2011, 2(23).

6. Aizawa M, Yang C. Green credit, green stimulus, green revolution? China's mobilization of banks for environmental cleanup[J]. The Journal of Environment \& Development, 2010, 19(2): 119-144. 